\title{
The connection between trust and leadership styles in Slovene organizations*
}

\author{
Jure Kovač, Manca Jesenko**
}

In leadership, trust between superiors and subordinates plays a very important role. This article presents the results of empirical research covering the connection between the level of trust within an organization and leadership styles, which were defined in a dichotomous way (democratic vs. nondemocratic). In order to understand the mutual connection between trust and leadership on a deeper level, we selected delegation, communication and control as important elements in the leadership process. The results obtained in the analyses indicate the connection between the level of democracy in leadership styles and the level of formalisation in delegation, communication and the control of the tasks of one's subordinates, as well as the democracy in leadership and the level of trust.

Bei Führung spielt Vertrauen zwischen Vorgesetzten und Untergebenen eine wichtige Rolle. Der Artikel beschäftigt sich mit den Ergebnissen der empirischen Forschung bezüglich des Zusammenhangs zwischen dem Ausmaß an Vertrauen innerhalb von Organisationen und den Führungstypen, die in dichotomer Form definiert werden (demokratisch vs. nicht demokratisch). Um den wechselseitigen Zusammenhang zwischen Vertrauen und Führung besser verstehen zu können, wurden Delegation, Kommunikation und Kontrolle als wichtige Elemente des Führungsprozesses ausgewählt. Die Ergebnisse der Analyse zeigen einen Zusammenhang zwischen dem Ausmaß an demokratischer Führung und dem Formalisierungsgrad, der bei Delegation, Kommunikation und Kontrolle der Aufgaben von Untergebenen angewendet wurde, sowie einen Zusammenhang zwischen demokratischer Führung und Ausmaß an Vertrauen.

Key words: trust, organisation,leadership, leadership styles, conmmunication, delegating, control

* Manuscript received: 22.01.09, accepted: 30.07 .09 (1 revision)

** Jure Kovač, Associate Prof., Faculty of Organizational Sciences, University of Manbor, Slovenia. Main research areas: Organizational theory, management development and organizational design. Corresponding address: jure.kovac@fov.uni-mb.si.

Manca Jesenko, Faculty of Organizational Sciences, University of Manbor, Slovenia. Main research areas: Statistics, quantitative methods and decision theory. Corresponding address: manca. jesenko@fov.uni-mb.si. 


\section{Introduction}

In the previous decade, there has been a considerable increase in researching trust at the organizational level. There are several reasons for this. Zeffane and Connell wrote "that researchers and practitioners continue to recognise trust as an important factor in determining organizational success, organizational stability and the well-being of employees" (Zeffane/Connell 2003:1). In addition, trust within an organisation is gaining in importance due to new organisational forms such as network organisations and knowledge organisations. Thus, an author like Bleicher, who developed the concept of the "organization of trust" (Vertauensorganistaion) (Bleicher 1991:72), defines the "organization of trust" in his latest observations as the foundation stone of a modern organisation. Bleicher considers "an intelligent company" where trust is "the glue that holds organizations together" to be the organisational form of the future (Bleicher 2009:73).

Research into the role and significance of trust in organisations is not a recent innovation. In its function within an organisation, trust is related through elements such as power, control and other limitations, including intimidation as well as statutory and hierarchical authority. Studies in this field provide the following forms of trust established (between members of organisation) within an organisation: trust based on intimidation (this produces very fragile relations); trust based on expertise; and trust emerging from the overlapping of interests. The types of trust between members of an organisation certainly depend on individual situational factors (Robbins/DeCenzo 2001:368; Schweer/Thies 2003).

One will look in vain trying to find a uniform view in the expert literature of the role and importance of trust in an organization. Individual representatives of the different "schools" have vastly differing views on the role and importance of trust. The author of the theory on transaction costs, Oliver Williamson, highlighted the role and importance of trust in individual transactions in his early works (1975). In his subsequent work (Williamson 1985/1993), the significance of trust in organizations was downgraded to the level of personal opportunism. Hill (1990), on the other hand, made the opposite claim: organizations with a high level of trust have lower transaction costs and are therefore more effective in the long run. Kramer and Cook (2004:2) have noted that research on organizational trust addresses three main issues. The first theme has been the constructive effect of trust with respect to reducing transaction costs within organizations. Secondly, the role trust plays in spontaneous sociability among organizational members has been explored. Thirdly, there has been an appreciation of how trust facilitates appropriate forms of deference to organizational authorities.

In recent times, researching the role and importance of trust has been given fresh impetus (Nooteboom 2002:2). Authors such Barney and Hansen (1994), 
Fukuyama (1995), Zeffane and Connell (2003), as well Bijlsam-Frankema et al. (2008) define the role of trust in much broader terms. They believe that trust can be a source of competitive advantage for a particular organization. Trust can therefore be placed among factors that affect the success and efficiency of an organization. In doing so, they emphasise that a higher level of trust within an organisation can contribute to:

$>$ Open forms of communication

$>$ Lower levels of formality

$>$ Simplified forms of coordination

$>$ Lower transaction costs

$>$ More stable interpersonal and inter-organizational connections (Staehle 1999:409; Zeffane/Connell, 2003:3; Schweer/Thies 2003:59; Bijlsam-Frankema et al. 2008:22; Bleicher 2009).

As we can see, the field of studying trust within an organisation is very extensive, and understanding the role of trust between superiors and subordinates has a special place in this research. Therefore, we will hereinafter focus on studying trust within an organisation, paying special attention to the field of trust between superiors and the subordinates. Further, the notion of trust shall be used here with a broad meaning, as a positive expectation that our partners will not act opportunistically - in a self-interested way - through their words, actions or decisions, regardless of the possibilities and opportunities. This is not to say that trust is unconditional and unlimited. There are certain restrictions or limitations that the environment sets to organizations and individuals in their perception and interpretation of trust.

\section{Trust between leaders and their subordinates}

Bleicher writes that the relationship between superiors and subordinates may be based on trust or on fear (Bleicher 2009). To be more precise, Bleicher believes that "in addition to fear, trust is one of the ways of keeping the social system together" (Bleicher 2009:72). Ghilic-Micu and Stoica write that "fear is the opposite of trust in the workplace" (2003:16) and emphasise the negative consequences of fear taking over at the workplace. The negative influences of fear on the efficiency of performing work tasks have been confirmed by numerous researchers. Thus, Schein (1995) confirmed the negative influences an atmosphere of fear has on learning processes within an organisation (Kramer/Cook 2004:264). Bibb and Kourdi are even more forthright when they write that "low trust cultures are characterised by fear of the boss and fear of making a mistake because of the repercussions. The sort of behaviour that you see in such cultures is caution, lack of risk taking as well as passive acceptance and lack of challenge to authority" (Bibb/Kourdi 2007). In contrast, a high level of trust leads to "synergy and performance" (Ghilic-Micu/Stoica 2003:17; $\mathrm{Bibb} /$ Kourdi 2007:23). Therefore, it is in the interest of each leader to develop a 
high level of trust in relation to his or her subordinates. We will hereinafter focus predominantly on exploring the scope and importance of trust between superiors and subordinates.

The role of trust between leaders and their subordinates has been the subject of research from numerous different disciplines, including organizational psychology, management, and public administration. Transformational and charismatic leaders trust their followers (Kirpatrick/Locke 1996; Podsakoff et al. 1990). Trust is an important element of effective behaviour (Fleishman/Harris 1962) and leader-member exchange behaviour (Schriesheim et al. 1999). Other studies show that promoting trust can be important for leader effectiveness (Bass 1990; Hogan et al. 1994).

Most of the existing studies state that the process of building trust between leaders and subordinates lies in the hands of leaders. Hence, in their research Dirks and Ferrin (2002) have discerned "substantial relationships between perceptions of leadership actions, including transformational leadership $(\mathrm{r}=.72)$, interactional justice $(\mathrm{r}=.65)$, participative decision making $(\mathrm{r}=.46)$, and failure to meet expectations of subordinates $(\mathrm{r}=.40)$, as well as others. In short, trust in leadership appears to be associated with a well-established set of leadership actions and behaviours" (Dirks/Skarlicki 2004:33).

On the basis of their research, Dirks and Skarlicki (2004:33) conclude: "Trust in leadership appears to be associated with a well-established set of leadership actions and behaviours." Andersen (2005:402) came to similar conclusions. In his article, he exposes the connection between the activity of superiors and the trust of their subordinates. From his findings, it results that superiors gain the trust of their subordinates with their activity, and the level of trust between superiors and their subordinates differs with regard to hierarchical level in an organization. Researchers have shown that the leader's efforts to build trust are key mechanisms for enhancing organizational effectiveness (Barney/Hansen 1994).

From the ideas represented above, it can be concluded that trust in superiors has many advantages for individuals as well as organizations. Building trust between superiors and subordinates is extremely important for a successful and effective operation of an organization.

\section{Research}

\subsection{Theoretical basis and methodology}

In the research into trust within organizations that we have performed, we found that different levels of trust exist within organizations, according to the individual hierarchical levels. (Kovač/Jesenko 2004). The findings obtained in the research from 2006 are of particular importance; we found that an increased 
level of trust within an organization contributes to a reduced level of formalization within an organization (Kovač/Jesenko 2006).

In 2008, we carried out new research with the desire of deepening the understanding of the impact and significance of trust within the organization, with a special emphasis on the connection between the level of trust and the leadership styles within an organization. We decided to explore the connection between leadership styles and trust because of findings that leadership actions and behaviours are the greatest contributors to increasing trust between superiors and subordinates. A leader's work is best manifested in his or her leadership style (Whitener et al. 1998; Dirks/Skarlicki 2004; Andersen 2005).

We chose Bleicher's concept of the "organization of trust" (Vertauensorganistaion) (1991) as the basic theoretical model. Bleicher believes that the development of organisations in the second half of the 20th century moved from a rigid bureaucratic form, with distrust on the part of superiors towards the subordinates as a key feature, towards a more adaptable informal organisation based on a high level of trust between the members (1991:70-75). The author presented an integrated view, i.e. the characteristics of the "organization of trust" in comparison with the "organisation of distrust." From his model, we took the basic finding that relationships between superiors and subordinates within the "organization of trust" are based on less formal mutual relations or cooperation (Bleicher 1991:76). This finding represented the starting point for conceiving our research model.

The basic relationship between superiors and subordinates within an organisation is formed through the leadership process. The basic form of the leadership process within an organisation is manifested in the so-called leadership style, which can be defined as a relatively permanent pattern of influence on the subordinates with the goal of mutually achieving set objectives (Staehle 1999:334). In theory, leadership styles are shown for the most part as dichotomous models (autocratic vs. democratic, directive vs. participatory, etc.) (Bass 1990:415).

For our research, we adopted the leadership styles definitions from the questionnaire that was prepared within the framework of the INTERKULT research project on intercultural comparison from 1994 (Lang et al. 1996). The behaviour of leaders thus comprises coherent, "to be" notions that are realised with the aid of leadership instruments (Lindert 1996:91). The manner and form of using influential mechanisms for directing co-workers towards achieving objectives have been defined in the four possible varieties of leadership styles; they are marked as L1, L2, L3 and L4. Thus, they represent: 
L1: Capable of making immediate decisions. Communicates his decisions to co-workers in a clear and assertive manner. Expects co-workers to be loyal and not to cause problems when implementing and executing his decisions.

L2: Capable of making immediate decisions. Prior to their implementation, he tries to explain his decisions in detail to the co-workers. He justifies his decisions and answers all questions from the co-workers.

L3: Usually, he discusses the issue with his co-workers first and takes their suggestions into consideration when making a decision. However, he expects everyone to participate in the realization of his decision, even though it may not be in line with what they had suggested.

L4: When an important decision has to be made, he usually organises a meeting. He explains the problem to co-workers and encourages discussion. The head makes a decision based on the majority opinion.

With a more in-depth understanding of the scope of trust between superiors and subordinates, exploring the connection between the leadership style and the level of trust can be seen as too superficial. In order to understand the mutual connection between trust and leadership on a deeper level, we selected delegation, communication and control as important elements in the leadership process (Bass 1990:402). The manner and form of the implementation of control, communication and delegation is, to a great extent, related to leadership style (Bass 1990:27).

We decided to select communication, delegation and control as elements of the leadership process because they occur most frequently in the research related to trust between superiors and subordinates within an organization. Based on the research by Whitner et al. (1998:513), the following factors contribute the most to increasing trust between leaders and subordinates:
$>$ behavioural consistency
$>$ behavioural integrity
$>$ delegation and control
$>$ communication
$>$ demonstration of concern

It can be shown that delegating, controlling and communicating as important elements in the leadership process (Bass 1990). This is why we focused especially on the stated factors within the leadership process for the continuation of our research.

In order to understand the connection between the selected elements of the leadership process (delegation, control and communication), we examined the research findings obtained thus far. Authors like Das/Teng 1998 and Schweer/Thies 2003 found that a certain level of control is necessary in most 
organisations. Although trust can simplify the controlling process (Neubauer/Rosemann 2006:134), it cannot completely eradicate or substitute it. Trust can only decrease the controlling process's complexity.

In the field of communications, authors such as Zand (1977) and Korsgaard/Roberson (1995) emphasise that trust is one of the central elements in the communication process within an organisation (Schweer/Thies 2003:78). The level of trust influences the quality of the communication process itself and increases its openness and intensity. Research carried out by Willemyns et al. (2003) in the field of communication between superiors and subordinates showed that the more the superiors in the communication process (communication style) emphasise their position within an organisational structure, the lower the level of trust between the superior and the subordinates (Neubauer/Rosemann 2006:137).

We understand delegation as a process of empowerment by ones' subordinates, who can take responsibility for certain activities. Bass writes that "the degree of delegation is associated with the trust the superior has for the subordinate" (Bass 1990:312). The form of delegation depends on the trust between the superiors and the subordinates (Whitener et al. 1998:517). Therefore, in an organisation with a lower level of trust, we find a higher level of complexity in the delegation process (Bijlsam-Frankema et al. 2008:22). A higher level of formalisation and excessive regulation is a reflection of this higher level of complexity in the delegation process (Bleicher 1991:74).

We defined the forms and manners of implementing communication, delegation and the control of tasks from the perspective of a greater or lesser level of formalisation. Thus, we determined that leaders within the leadership process may use both formal (written) and informal (oral) forms when communicating, delegating and controlling tasks.

\subsection{Hypotheses and the sample structure}

This research stemmed from the basic premise that leaders enjoy different levels of trust within an organisation due to their leadership style. Leaders apply a greater or a lesser degree of formalisation according to the leadership style that individual leaders implement. Based on these starting points, we created two working hypotheses that served as the basis for data analysis:

H1: The higher the level of formalization in the processes of task delegation, communication and control, the lower the perception of the leader's democratic approach in the eyes of his subordinates.

H2: The more democratic leaders enjoy a higher level of trust than the less democratic leaders do.

When measuring the perception of the leader's "democratic" approach, we used the four previously defined leadership styles. We can therefore observe that the 
democratic approach increases as we progress from the type L1 leader to the type L4 leader.

Since we found in our previous research that such a definition is relatively rigid, we decided to measure the individual elements that define the types of leaders presented above for this research. The individual elements present typical characteristics of theoretically defined leaders, as described above. In this research, we measured these elements in the form of statements, i.e. we asked the surveyed respondents to grade the extent they believe the statements apply to their superiors using a scale from 1 (I don't agree at all) to 5 (I fully agree). All the statements are presented in the section "Defining the types of leaders from the democratic leadership styles." Since certain elements connect content-wise based on the level of democracy in leadership styles, we hereinafter determined the different types of leaders on the basis of cluster analysis. Based on the perception of individual elements, we later defined different groups of leaders that differ according to their level of democracy in leadership styles.

Other elements studied (trust, the delegation of tasks, the level of communication and control) have a multi-dimensional nature; therefore, they were measured in the research questionnaire indirectly. We determined individual factors (in order to best define an individual element) on the basis of the organization's practical operation.

We measured the trust in different levels of organization, because we wanted to obtain an integrated picture of the trust within the organization as a whole. Consequently, the respondents evaluated trust within an organization in a general sense, among the top leaders, their superiors and subordinates, and among the organizational units. The other three dimensions (the delegation of tasks, communication and control) were defined in the research questionnaire from the formal and informal points of view.

\section{About the sample}

In performing this research, we wanted to obtain an insight into the connection between a democratic leadership style and the formal and informal elements of the leadership process. We obtained the data with the help of employees and part-time students from our faculty. The selection of the sample was random from the perspective of the active population in Slovenia. Out of 300 questionnaires distributed, we received 104 completed ones, or $34.6 \%$. With this research, we wanted to ascertain whether indications exist of the expected connections between the phenomena studied. Therefore, it is essential to ensure the representativeness of the studied phenomena with the sample (Coenders et al. 2003).

Although the sample is not representative from the perspective of the Slovene population of active companies, the following description of the sample shows a 
satisfying variety of data that can offer information on the desired connections between the phenomena studied. The results demonstrate the appropriate representativeness of the phenomena studied. The data was obtained using a questionnaire of 18 questions and divided into five chapters (general information, employment information, leadership style, trust, leadership process and organization elements).

As can be seen in Table 1, $8 \%$ of the sample are directors, nearly $20 \%$ are heads of sectors, $40 \%$ are the heads of departments or groups and around $34 \%$ are professional employees without a leadership role.

Table 1. Sample structure

\begin{tabular}{|c|c|c|}
\hline \multirow{6}{*}{$\begin{array}{l}\text { Position } \\
\text { within an } \\
\text { organization }\end{array}$} & Director & $8 \%$ \\
\hline & Head of the sector & $18 \%$ \\
\hline & $\begin{array}{l}\text { Head of the } \\
\text { department }\end{array}$ & $31 \%$ \\
\hline & Head of a group & $9 \%$ \\
\hline & $\begin{array}{l}\text { Professional } \\
\text { employee }\end{array}$ & $34 \%$ \\
\hline & Clerk & $1 \%$ \\
\hline \multirow{6}{*}{$\begin{array}{l}\text { Number of } \\
\text { employees in } \\
\text { your } \\
\text { company }\end{array}$} & $<50$ & $20 \%$ \\
\hline & $50-99$ & $13 \%$ \\
\hline & $100-499$ & $26 \%$ \\
\hline & $500-999$ & $18 \%$ \\
\hline & $1000-5000$ & $18 \%$ \\
\hline & $>5000$ & $5 \%$ \\
\hline
\end{tabular}

\begin{tabular}{|c|c|c|}
\hline \multirow{2}{*}{ Gender } & Men & $54 \%$ \\
\hline & Women & $46 \%$ \\
\hline \multirow{3}{*}{ Age } & Less than 35 & $22 \%$ \\
\hline & 35 to 50 years & $61 \%$ \\
\hline & More than 50 & $17 \%$ \\
\hline \multirow[t]{2}{*}{ Education } & $\begin{array}{l}\text { University degree } \\
\text { or specialization }\end{array}$ & $54 \%$ \\
\hline & Master's degree & $46 \%$ \\
\hline \multirow{9}{*}{ 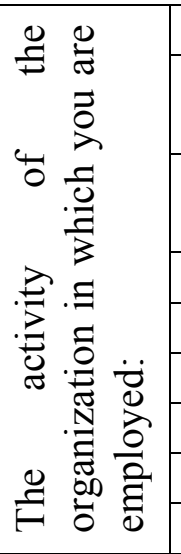 } & Trade & $13 \%$ \\
\hline & $\begin{array}{l}\text { Banking and } \\
\text { financial services }\end{array}$ & $9 \%$ \\
\hline & $\begin{array}{l}\text { Information } \\
\text { technology services }\end{array}$ & $6 \%$ \\
\hline & Other & $8 \%$ \\
\hline & Industry & $18 \%$ \\
\hline & Education & $14 \%$ \\
\hline & The health sector & $11 \%$ \\
\hline & State / municipalities & $17 \%$ \\
\hline & Other & $6 \%$ \\
\hline
\end{tabular}

The sample includes approximately the same number of men and women; in terms of age, respondents between 35 and 50 prevail. The sample shows a relatively high educational level as $54 \%$ of respondents have a university degree or completed specialization, while $46 \%$ have a Masters' degree. The structure of the organisations that the respondents come from is highly heterogeneous. Industrial companies are represented with the largest share of $18 \%$, closely followed by state administration with $17 \%$. Organisations and the educational sector have a share of $14 \%$, while the trade sector has $13 \%$. The banking sector follows with $9 \%$, other service sectors have a share of $8 \%$, information technology has a share of $6 \%$ and other fields of activity a share of $6 \%$. Irrespective of the fact that the structure of the organisations that the respondents come from is markedly heterogeneous and that the structure includes the 
industrial and the service sectors, as well as state administration, we cannot consider the sample to be representative in terms of the distribution of the active population in Slovenia.

\subsection{Results of the research}

\section{Defining the types of leaders from the democratic leadership styles}

Since our previous experience shows that this differentiation of the types of leaders is relatively rigid, we decided for this research to separately measure the elements of democracy or non-democracy that determine the types of leaders described above. Therefore, we asked the respondents the extent to which they agree that individual elements hold true for their superiors. Later, we classified the types of leaders using cluster analysis. We decided on hierarchical clustering, in which we took the Squared Euclidean Distance as a measure of difference, whereas the similarity or difference between clusters was measured using the Ward method, which maximises the homogeneity within clusters.

Classifying the units into clusters showed four sensible groups of leader types. Their features are expressed by the averages of the individual elements.

Table 2. The average values of the evaluated elements of leadership styles

\begin{tabular}{|l|c|c|c|c|}
\hline & L1 & L23 & L4 & L0 \\
\hline Immediately makes decisions & $\mathbf{3 . 8}$ & $\mathbf{3 . 7}$ & 2.7 & 1.9 \\
\hline $\begin{array}{l}\text { Informs co-workers of his decisions in a clear and assertive } \\
\text { manner }\end{array}$ & 3.4 & $\mathbf{4 . 5}$ & 3.0 & 1.8 \\
\hline $\begin{array}{l}\text { Expects co-workers to be loyal and not to cause problems when } \\
\text { implementing and executing his decisions. }\end{array}$ & $\mathbf{4 . 4}$ & $\mathbf{4 . 8}$ & 3.4 & 2.9 \\
\hline $\begin{array}{l}\text { Prior to their implementation, he tries to explain his decisions in } \\
\text { detail to co-workers }\end{array}$ & 2.4 & $\mathbf{4 . 0}$ & $\mathbf{4 . 0}$ & 2.0 \\
\hline $\begin{array}{l}\text { Justifies his decisions and answers all questions from the co- } \\
\text { workers. }\end{array}$ & 2.3 & $\mathbf{4 . 0}$ & $\mathbf{4 . 1}$ & 1.9 \\
\hline $\begin{array}{l}\text { Usually discusses the issue with his co-workers before making } \\
\text { a decision. }\end{array}$ & 2.3 & $\mathbf{3 . 6}$ & $\mathbf{4 . 1}$ & 2.6 \\
\hline $\begin{array}{l}\text { When making a decision, takes their suggestions into } \\
\text { consideration. }\end{array}$ & 2.6 & $\mathbf{4 . 0}$ & $\mathbf{4 . 1}$ & 2.5 \\
\hline $\begin{array}{l}\text { Expects everyone to participate in the realization of his } \\
\text { decision, even though it may not be in line with what they had } \\
\text { suggested. }\end{array}$ & $\mathbf{4 . 2}$ & $\mathbf{4 . 6}$ & $\mathbf{3 . 6}$ & $\mathbf{3 . 6}$ \\
\hline $\begin{array}{l}\text { When an important decision has to be made, usually organises a } \\
\text { meeting. }\end{array}$ & 2.8 & $\mathbf{4 . 0}$ & $\mathbf{4 . 0}$ & 2.4 \\
\hline Explains the problem to them and encourages discussion. & 2.3 & $\mathbf{4 . 0}$ & $\mathbf{3 . 9}$ & 2.5 \\
\hline Makes a decision based on the majority opinion. & 2.4 & 2.9 & $\mathbf{3 . 5}$ & 2.0 \\
\hline
\end{tabular}

We can observe a clear line of separation between the first and third groups, which provisionally reflect the extremes of the previously defined four types of 
leaders. Therefore, the first group was marked as type L1, which represents the least democratic type of a leader. The third group, type L4, represents the most democratic type of leader. The second group is positioned between the two extremes, as it shows elements from both the first and the fourth group. The last group is different from the other types of leaders. The only element that defines this group, is that a leader "expects everyone to participate in the realization of his decision, even though it may not be in line with what they had suggested." We could say that the employees cannot classify such a leader as authoritative or as democratic. It seems that the behaviour of such a leader is perceived as feeble, indecisive and uncooperative. This group was marked as type L0.

Figure 1 shows the presence of the group leaders formed in the sample. While the first three groups show nearly equal presence, the last group (L0) represents over $10 \%$ of the sample. The connection between the various types of leader and the manner of task delegation, communication and control.

Figure 1. The structure of the types of leaders

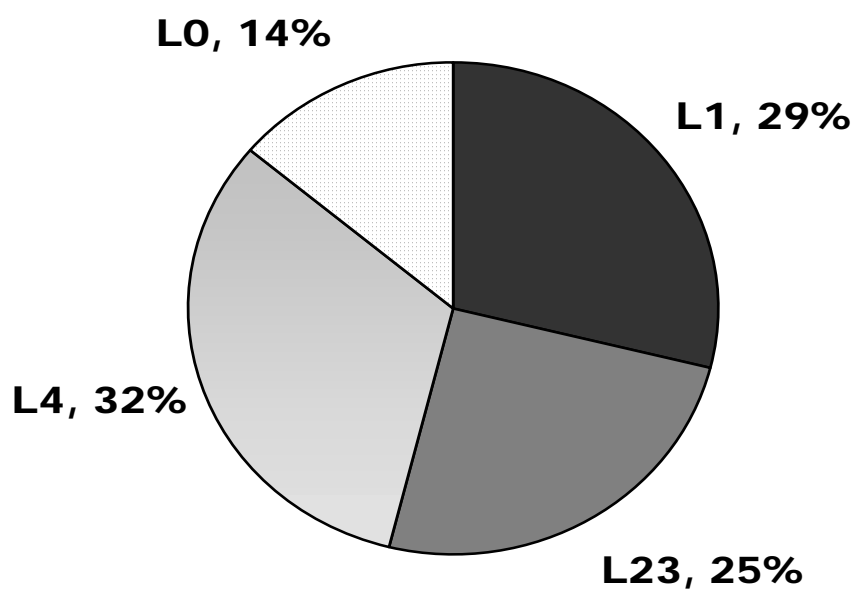

In further analyses, we wanted to first check whether statistically significant differences exist between the various types of leaders in the individual factors of the delegation of tasks, the types of communication and performing control. For this purpose, we used the One-Way ANOVA to compare the average values of the four independent samples. We found that statistically significant differences occur on all three elements of the leadership process.

\section{The delegation of tasks}

With the delegation of tasks, we offered the respondents four choices to which they said how often they were used within their organization. They replied on a five-level scale (1- Never,.. 5 - Always) on how often tasks are delegated in written form, through co-workers, orally or in combination of the three.

Figure 2 shows that, within the organizations surveyed, on average, tasks are most frequently delegated orally and least frequently through co-workers. 
Figure 2. The average frequency of the delegation of tasks

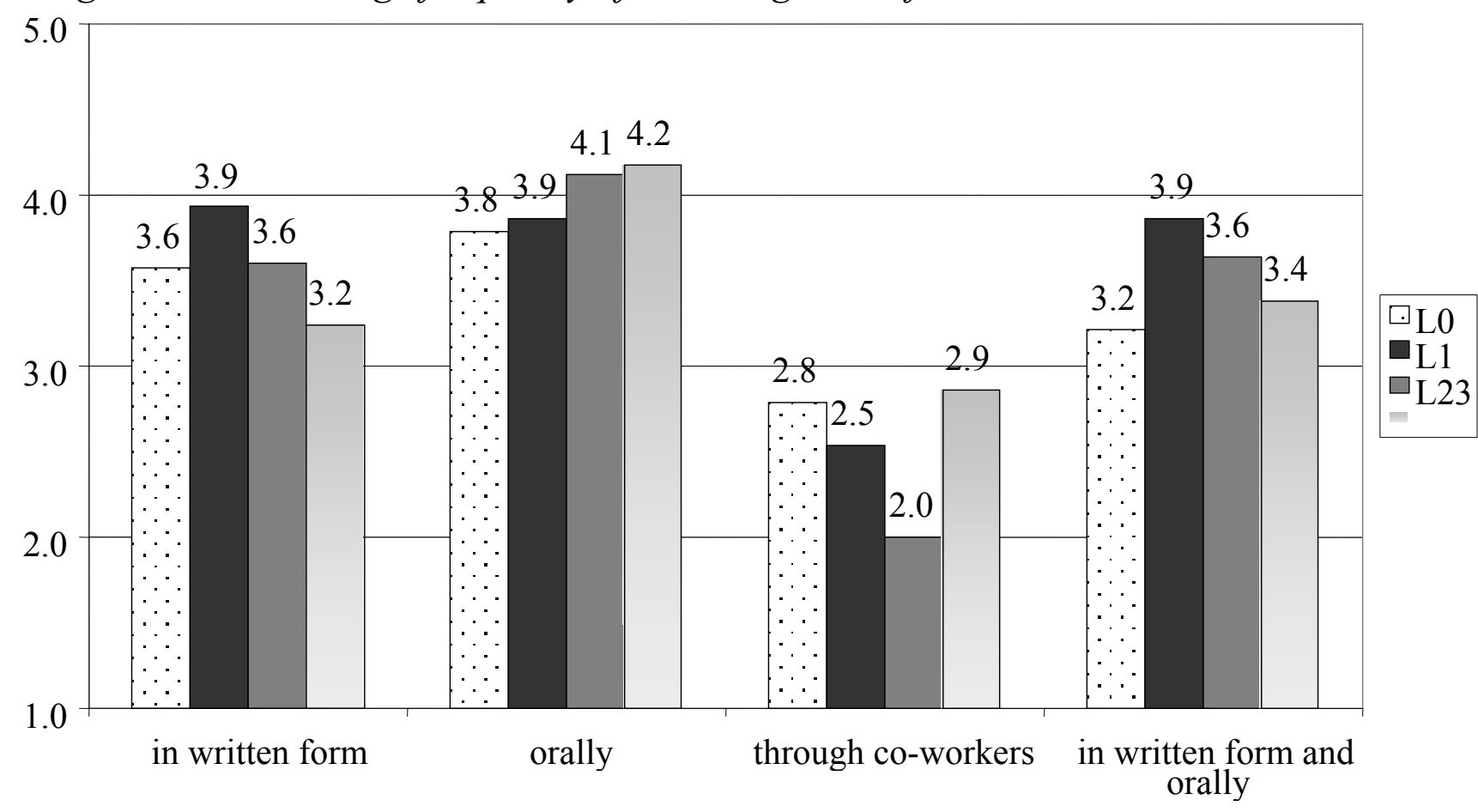

Table 3 shows that significant differences occur between the four types of leaders in the frequency of the written delegation of tasks $(\mathrm{p}=0.055)$ and in the frequency of the delegation of tasks through co-workers $(\mathrm{p}=0.028)$.

Table 3. ANOVA for Equality of Means between the different types of leaders for the ways of delegating tasks

\begin{tabular}{|c|c|c|c|c|c|c|}
\hline & & $\begin{array}{l}\text { Sum of } \\
\text { Squares }\end{array}$ & $\mathrm{df}$ & $\begin{array}{l}\text { Mean } \\
\text { Square }\end{array}$ & $\mathrm{F}$ & Sig. \\
\hline \multirow{3}{*}{ Written } & Between Groups & 6.737 & 3 & 2.246 & \multirow{3}{*}{2.629} & \multirow{3}{*}{0.055} \\
\hline & Within Groups & 78.596 & 92 & 0.854 & & \\
\hline & Total & 85.333 & 95 & & & \\
\hline \multirow{3}{*}{ Oral } & Between Groups & 2.426 & 3 & 0.809 & \multirow{3}{*}{1.315} & \multirow{3}{*}{0.274} \\
\hline & Within Groups & 56.564 & 92 & 0.615 & & \\
\hline & Total & 58.990 & 95 & & & \\
\hline \multirow{3}{*}{$\begin{array}{l}\text { Through } \\
\text { co-workers }\end{array}$} & Between Groups & 10.654 & 3 & 3.551 & \multirow{3}{*}{3.172} & \multirow{3}{*}{0.028} \\
\hline & Within Groups & 100.750 & 90 & 1.119 & & \\
\hline & Total & 111.404 & 93 & & & \\
\hline \multirow{3}{*}{$\begin{array}{l}\text { Written } \\
\text { and oral }\end{array}$} & Between Groups & 5.252 & 3 & 1.751 & \multirow{3}{*}{2.225} & \multirow{3}{*}{0.090} \\
\hline & Within Groups & 72.373 & 92 & 0.787 & & \\
\hline & Total & 77.625 & 95 & & & \\
\hline
\end{tabular}

By using even comparisons between the average values of groups, we found that, in comparison with other types of leaders, type L1 leaders delegate tasks in writing more frequently. Statistically significant differences occur when compared with type L4 leaders ( $\mathrm{p}=0.006$ ). Similarly, the delegation of tasks both orally and in writing is more frequent in type L1 leaders than with other types of 
leaders. Statistically significant differences occur when compared with type L0 leaders $(\mathrm{p}=0.029)$ and type L4 leaders $(\mathrm{p}=0.045)$.

Type L0 and type L4 leaders delegate tasks through co-workers more frequently than other types of leaders. Statistically significant differences occur when compared with type L23 leader (pL0-L23=0.030, pL4-L23=0.005).

\section{Communication}

Communication within organizations was measured on a five-level scale ( 1 - I don't agree at all,... 5 - I fully agree), based on the following statements: we have regular meetings with employees - only of a formal nature; communication is based on fixed procedures and rules; we have regular meetings with employees - including those of an informal nature; communication is based on defined and introduced forms, our system of communication is very open.

The frequency of individual communication styles is shown in Figure 3, which demonstrates that, on average, the respondents most agree with the claim that their system of communication is open. They agree least with the claim that communication is based on fixed procedures and rules.

Figure 3. The average agreement with the claims on the system of communication within organizations

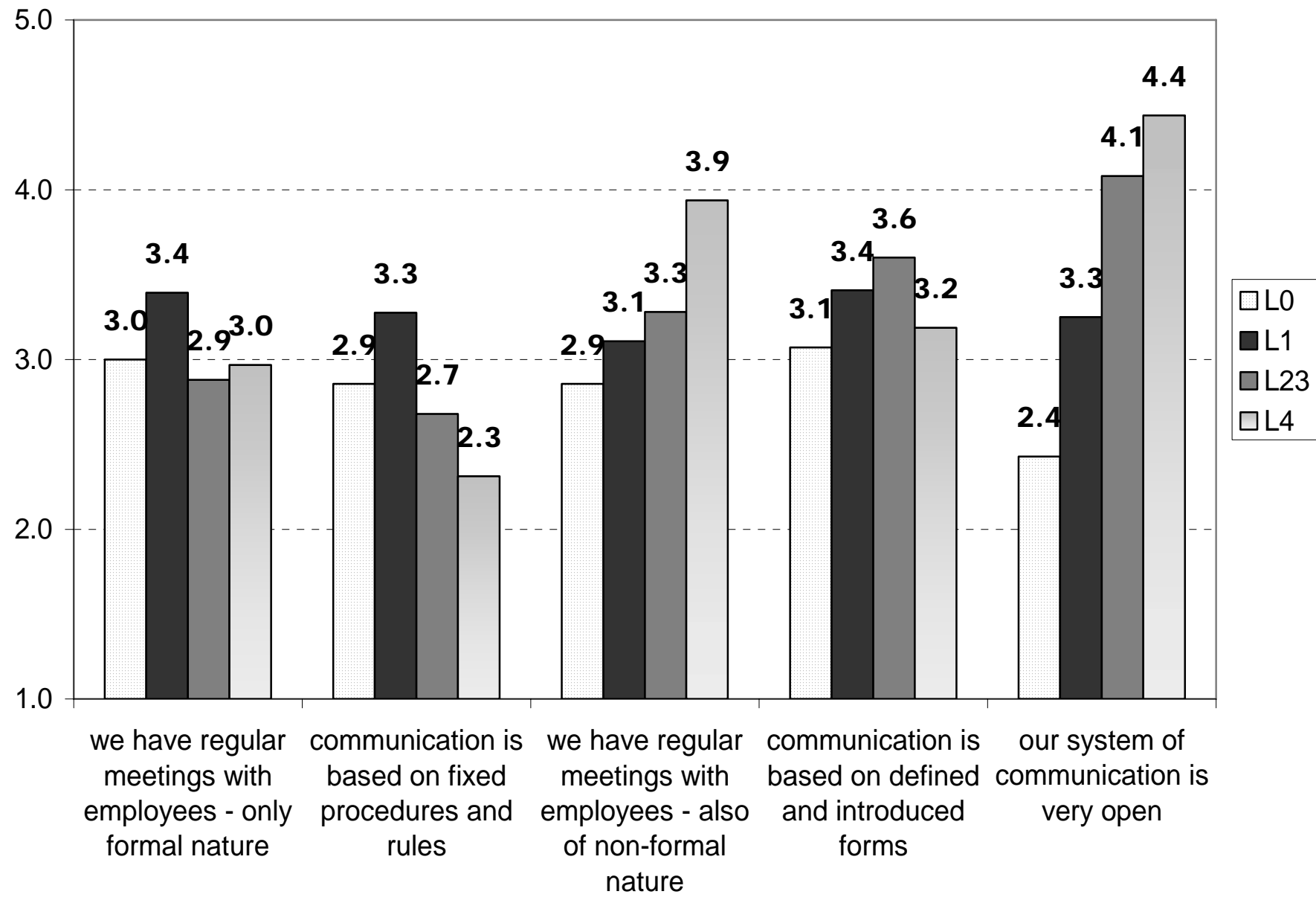


With analysis of variance (results are shown in Table 4), we can ascertain that statistically significant differences exist in the styles of communication defined as "communication is based on fixed procedures and rules," "we have regular meetings with employees - including those of an informal nature" and "our system of communication is very open."

With even comparisons between average group values, we established that the type L1 and L4 leaders differ with statistical significance $(\mathrm{p}=0.002)$ with regard to the implementation of fixed procedures and rules of communication, this being more typical of type L1 leaders. Type L4 leaders organise meetings more frequently and discuss informal themes as well; this is statistically significant in comparison with other types (pL4-L0 $=0.004$, pL4-L1 $=0.006$, pL4-L23=0.033). The openness of the system of communication showed statistically significant differences between nearly all pairs of leader types. No statistically significant differences were observed between the L23 and L4 pair of leaders (pL0$\mathrm{L} 1=0.021$, pL0-L23 $<0.001, \mathrm{pL} 0-\mathrm{L} 4<0.001, \mathrm{pL} 1-\mathrm{L} 23=0.006$, pL1-L4<0.001).

\section{Control}

Control in organizations was measured on the basis of the frequency of performing the five different types of controlling. We asked the respondents to mark on a five-level scale (1- Never,... 5 - Always) how frequently control is performed in their organization using oral reports, working meetings, coworkers, written reports and personal checking.

Table 4. ANOVA for Equality of Means between different types of leaders for different ways of communication

\begin{tabular}{|c|c|c|c|c|c|c|}
\hline & & $\begin{array}{c}\text { Sum of } \\
\text { Squares }\end{array}$ & $\mathrm{df}$ & $\begin{array}{l}\text { Mean } \\
\text { Square }\end{array}$ & $\mathrm{F}$ & Sig. \\
\hline \multirow{3}{*}{$\begin{array}{l}\text { We have regular } \\
\text { meetings with } \\
\text { employees - only of a } \\
\text { formal nature }\end{array}$} & Between groups & 4.218 & 3 & 1.406 & \multirow{3}{*}{0.952} & \multirow{3}{*}{0.419} \\
\hline & Within groups & 140.287 & 95 & 1.477 & & \\
\hline & Total & 144.505 & 98 & & & \\
\hline \multirow{3}{*}{$\begin{array}{l}\text { Communication is } \\
\text { based on fixed } \\
\text { procedures and rules }\end{array}$} & Between groups & 14.418 & 3 & 4.806 & \multirow{3}{*}{3.448} & \multirow{3}{*}{0.020} \\
\hline & Within groups & 133.822 & 96 & 1.394 & & \\
\hline & Total & 148.240 & 99 & & & \\
\hline \multirow{3}{*}{$\begin{array}{l}\text { We have regular } \\
\text { meetings with } \\
\text { employees - including } \\
\text { those of an informal } \\
\text { nature }\end{array}$} & Between groups & 16.106 & 3 & 5.369 & \multirow{3}{*}{4.136} & \multirow{3}{*}{0.008} \\
\hline & Within groups & 123.308 & 95 & 1.298 & & \\
\hline & Total & 139.414 & 98 & & & \\
\hline \multirow{3}{*}{$\begin{array}{l}\text { Communication is } \\
\text { based on defined and } \\
\text { introduced forms }\end{array}$} & Between groups & 3.566 & 3 & 1.189 & \multirow{3}{*}{0.913} & \multirow{3}{*}{0.438} \\
\hline & Within groups & 122.322 & 94 & 1.301 & & \\
\hline & Total & 125.888 & 97 & & & \\
\hline \multirow{3}{*}{$\begin{array}{l}\text { Our system of } \\
\text { communication is very } \\
\text { open }\end{array}$} & Between groups & 49.243 & 3 & 16.414 & \multirow{3}{*}{14.386} & \multirow{3}{*}{0.000} \\
\hline & & 108.394 & 95 & 1.141 & & \\
\hline & & 157.636 & 98 & & & \\
\hline
\end{tabular}


Figure 4 shows that, on average, control is most frequently performed using oral reports and least frequently through co-workers.

Figure 4. The average frequency of individual types of control

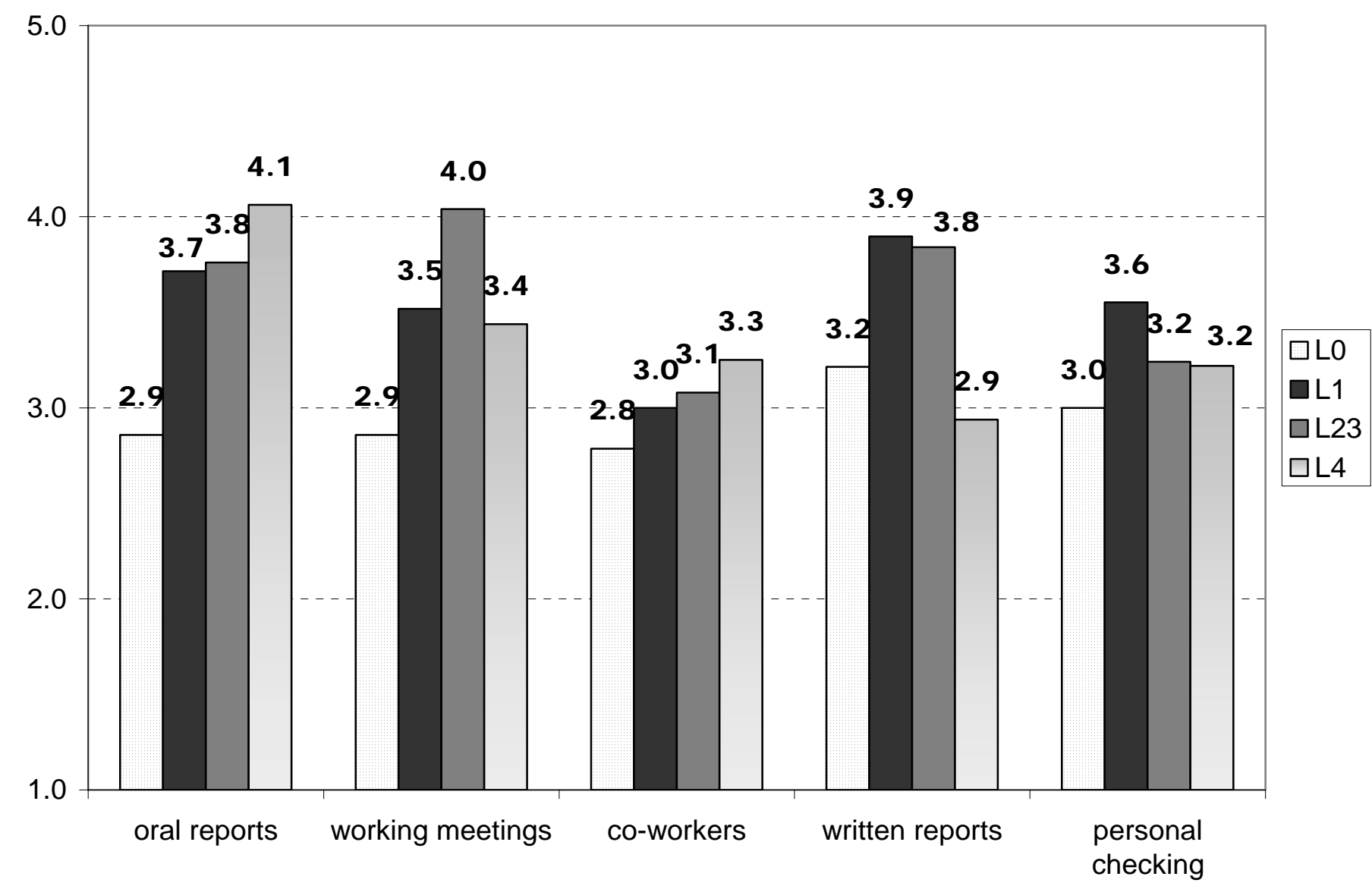

Analysis of variance showed (Table 5) that statistically significant differences occur when control is performed using oral and written reports and at working meetings.

Based on the paired tests performed between the group average values, we can establish that control through oral reports is statistically less frequent with type L0 leaders than with other types of leaders L0 (pL0-L1 $=0.009$, pL0-L23 $=0.007$, $\mathrm{pL0}$-L4 $<0.001)$. Moreover, controlling through working meetings is statistically the least significant for type L0 leaders ( $\mathrm{pL} 0-\mathrm{L} 1=0.027$, pL0-L23 $<0.001$, pL0L4=0.047). This type of control was statistically more frequent than the two other types of controlling with type L23 leaders (pL23-L1 $=0.036$, pL23L4=0.014). With control through written reports, statistically significant differences occur between type L1 and L4 leaders $(p=0.001)$ and type L23 and L4 leaders ( $\mathrm{p}=0.003)$. It is more frequent in type L1 and type L23 leaders.

The above analyses showed that, with individual elements of the leadership process, statistically significant differences occur between the various types of leaders from the perspective of the levels studied (the delegation of tasks, communication and control). How the individual types of leaders differ from the 
perspective of formal and informal approaches to the delegation of tasks, communication and control was studied with the aid of discriminant analysis. With discriminant analysis, we wished to establish whether the groups studied in a multi-dimensional space, determined by two or more (discriminant) variables, differ. The technique of discriminant analysis is based on the definition of a minimal number of new variables (discriminant functions), which are determined as a linear combination of discriminant variables in such a manner that the groups studied - with regard to the values of the discriminant functions - show the biggest differences.

Table 5. ANOVA for Equality of Means between the different types of leaders for control implementation

\begin{tabular}{|c|c|c|c|c|c|c|}
\hline & & $\begin{array}{l}\text { Sum of } \\
\text { Squares }\end{array}$ & $\mathrm{df}$ & $\begin{array}{l}\text { Mean } \\
\text { Square }\end{array}$ & $\mathrm{F}$ & Sig. \\
\hline \multirow{3}{*}{ Oral reports } & Between groups & 14.217 & 3 & 4.739 & \multirow{3}{*}{4.901} & \multirow{3}{*}{0.003} \\
\hline & Within groups & 91.864 & 95 & 0.967 & & \\
\hline & Total & 106.081 & 98 & & & \\
\hline \multirow{3}{*}{$\begin{array}{l}\text { Working } \\
\text { meetings }\end{array}$} & Between groups & 13.119 & 3 & 4.373 & \multirow{3}{*}{5.397} & \multirow{3}{*}{0.002} \\
\hline & Within groups & 77.791 & 96 & 0.810 & & \\
\hline & Total & 90.910 & 99 & & & \\
\hline \multirow{3}{*}{ Co-workers } & Between groups & 2.313 & 3 & 0.771 & \multirow{3}{*}{0.672} & \multirow{3}{*}{0.572} \\
\hline & Within groups & 110.197 & 96 & 1.148 & & \\
\hline & Total & 112.510 & 99 & & & \\
\hline \multirow{3}{*}{ Written reports } & Between groups & 18.678 & 3 & 6.226 & \multirow{3}{*}{4.969} & \multirow{3}{*}{0.003} \\
\hline & Within groups & 120.282 & 96 & 1.253 & & \\
\hline & Total & 138.960 & 99 & & & \\
\hline \multirow{3}{*}{$\begin{array}{l}\text { Personal } \\
\text { checking }\end{array}$} & Between groups & 3.389 & 3 & 1.130 & \multirow{3}{*}{1.335} & \multirow{3}{*}{0.267} \\
\hline & & 81.201 & 96 & 0.846 & & \\
\hline & & 84.590 & 99 & & & \\
\hline
\end{tabular}

In the case of $\mathrm{k}$ groups, we have $\min (G-1, p)$ discriminant functions (where $\mathrm{G}$ is the number of groups and $\mathrm{p}$ is the number of discriminant variables). We obtain them by building the matrix

$$
\begin{aligned}
& \mathrm{H}=\sum_{i=1}^{k} n_{i}\left(\bar{\xi}_{i \bullet}-\bar{\xi}_{. \bullet}\right)\left(\bar{\xi}_{i \bullet}-\bar{\xi}_{\bullet \bullet}\right)^{T} \text { and } \\
& \Xi=\sum_{i=1}^{n} \sum_{j=1}^{n}\left(\xi_{i j}-\bar{\xi}_{i \bullet}\right)\left(\xi_{i j}-\bar{\xi}_{i \bullet}\right)^{T}
\end{aligned}
$$

where $\xi_{i j}$ is the vector of variables for the $\mathrm{i}$-th unit of the j-th group, $\bar{\xi}_{i \bullet}$ is the vector of the arithmetic middle of the $\mathrm{i}$-th group and $\bar{\xi}_{\text {.. }}$ is the vector of arithmetic middle for all groups. Discriminant functions are built by taking vectors of the $\mathbf{a}_{\mathbf{i}}$ matrix $\boldsymbol{\Xi}^{-1} \mathbf{H}$, which belong among the non-null Eigenvalues, for coefficients of discriminant functions. If their number equals $\mathrm{s}$, we have the same number of discriminant functions:

$$
z_{1}=\mathbf{a}_{1}^{\mathbf{T}} \boldsymbol{\xi}, z_{2}=\mathbf{a}_{2}^{\mathbf{T}} \boldsymbol{\xi}_{\mathbf{2}}, \mathrm{L}, z_{s}=\mathbf{a}_{\mathbf{s}}^{\mathbf{T}} \boldsymbol{\xi}
$$


The discriminant function that separates the groups to the greatest extent is the one that belongs to the biggest Eigenvalue.

The delegation of tasks, communication and control were treated as multidimensional phenomena that can be performed in more formal and informal forms. The formal and informal approach perspective was considered in the elements with which we described the leadership processes studied. Discriminant variables used in the discriminant analysis were determined as the average level of the formal or informal elements of an individual level, which provided us with six new variables (the formal and informal delegation of tasks, formal and informal communication and formal and informal control). The elements included in an individual new variable are shown in Table 6.

Table 6. Defining the formal and informal levels of individual levels of the leadership process

\begin{tabular}{|c|c|c|}
\hline & FORMAL APPROACH & INFORMAL APPROACH \\
\hline $\begin{array}{ll}\text { DELEGATION OF } \\
\text { TASKS }\end{array}$ & $\begin{array}{l}\text { - Written } \\
\text { - Written and oral }\end{array}$ & $\begin{array}{l}\text { - Oral } \\
\text { - Through co-workers }\end{array}$ \\
\hline COMMUNICATION & $\begin{array}{l}\text { - We have regular meetings with } \\
\text { employees - only of a formal } \\
\text { nature } \\
\text { - Communication is based on } \\
\text { fixed procedures and rules } \\
\text { - Communication is based on } \\
\text { defined and introduced forms }\end{array}$ & $\begin{array}{l}\text { - We have regular meetings with } \\
\text { employees - including those of an } \\
\text { informal nature } \\
\text { - Our system of communication is } \\
\text { very open }\end{array}$ \\
\hline CONTROL & $\begin{array}{l}\text { - Working meetings } \\
\text { - Written reports }\end{array}$ & $\begin{array}{l}\text { - Oral reports } \\
\text { - Co-workers } \\
\text { - Personal checking }\end{array}$ \\
\hline
\end{tabular}

Table 7 shows the Eigenvalues, variance percentage and canonical correlation for each of the three possible discriminant functions. We can observe that we can explain $95 \%$ of the differences between the groups with the first two discriminant functions, $62 \%$ with the first and $33 \%$ with the second discriminant function.

With the help of Wilk's lambda, we can establish that the groups differ in a statistically significant manner with regard to the average of the first and second discriminant function (Table 8). Moreover, we can ascertain that the four groups of leader types are best differentiated - and in a statistically significant manner by two discriminant functions. 
Table 7. Eigenvalue, \% of variance, cumulative \% of variance and canonical correlation coefficient

\begin{tabular}{|c|c|c|c|c|}
\hline Function & Eigenvalue & \% of Variance & Cumulative \% & $\begin{array}{c}\text { Canonical } \\
\text { correlation }\end{array}$ \\
\hline 1 & $0.453(\mathrm{a})$ & 62.0 & 62.0 & 0.558 \\
\hline 2 & $0.242(\mathrm{a})$ & 33.1 & 95.1 & 0.441 \\
\hline 3 & $0.035(\mathrm{a})$ & 4.9 & 100.0 & 0.185 \\
\hline
\end{tabular}

The first three canonical discriminant functions were used in the analysis.

\section{Table 8. Wilk's lambda}

\begin{tabular}{|c|c|c|c|c|}
\hline Test of function(s) & Wilk's lambda & Chi-square & df & Sig. \\
\hline 1 through 3 & 0.535 & 53.775 & 18 & 0.000 \\
\hline 2 through 3 & 0.778 & 21.637 & 10 & 0.017 \\
\hline 3 & 0.966 & 2.995 & 4 & 0.559 \\
\hline
\end{tabular}

How the selected discriminant functions are connected with the independent variables is shown in Table 9, which shows correlations between the discriminant variables included in the analysis and the selected discriminant function. We can observe that the first discriminant function is best explained by informal communication and informal control, both being positively connected with it, while the second function is positively connected with the formal elements of the leadership process. We also can observe a rather high negative connection with the informal delegation of tasks.

Table 9. Pooled within-group correlations between the discriminating variables and standardised canonical discriminant functions

\begin{tabular}{|l|c|c|}
\hline & \multicolumn{2}{|c|}{ Function } \\
\hline & 1 & 2 \\
\hline Informal communication & $0.799\left(^{*}\right)$ & -0.299 \\
\hline Informal control & $0.444\left(^{*}\right)$ & -0.124 \\
\hline Formal control & 0.146 & $0.760\left(^{*}\right)$ \\
\hline Formal delegation of tasks & -0.084 & $0.513\left(^{*}\right)$ \\
\hline Informal delegation of tasks & 0.072 & $-0.468\left(^{*}\right)$ \\
\hline Formal communication & -0.085 & $0.284\left(^{*}\right)$ \\
\hline
\end{tabular}

Variables ordered by the absolute size of correlation within function.

* Largest absolute correlation between each variable and any discriminant function.

Therefore, we can ascertain that the first discriminant function, which explains the greatest number of differences between the groups, presents an informal approach to leadership, whereas the second discriminant function presents a more formal approach to leadership processes.

Figure 5 shows group centroids for the first (informal approach) and the second discriminant function (formal approach). When comparing a type L1 leader with 
a type L23 leader and a type L4 leader, we can observe that it is typical for the type L1 leader to use more formal leadership elements and fewer informal leadership elements in a leadership process. When a type L23 leader is compared with other types, we notice his typical usage of both formal and informal leadership elements, whereas a type L4 leader uses mainly informal leadership elements and formal leadership elements to a lesser degree. The type L0 leader uses a significantly different approach that the other leaders. When compared with other types of leader, we notice that he uses fewer informal leadership elements, as well as fewer formal leadership elements. If viewed from the three levels of the leadership process discussed, this can lead us to believe that his cooperation with subordinates is small.

We have demonstrated that various types of leaders differ with regard to their use of formal and informal leadership approaches with regards to the three levels of the leadership process; in doing so, we concluded that democratic leaders use more informal leadership elements in their leadership styles (and/or fewer formal leadership elements), which proves our first working hypothesis.

Figure 5. A visual presentation of group centroids for the first (informal approach) and the second discriminant function (formal approach)

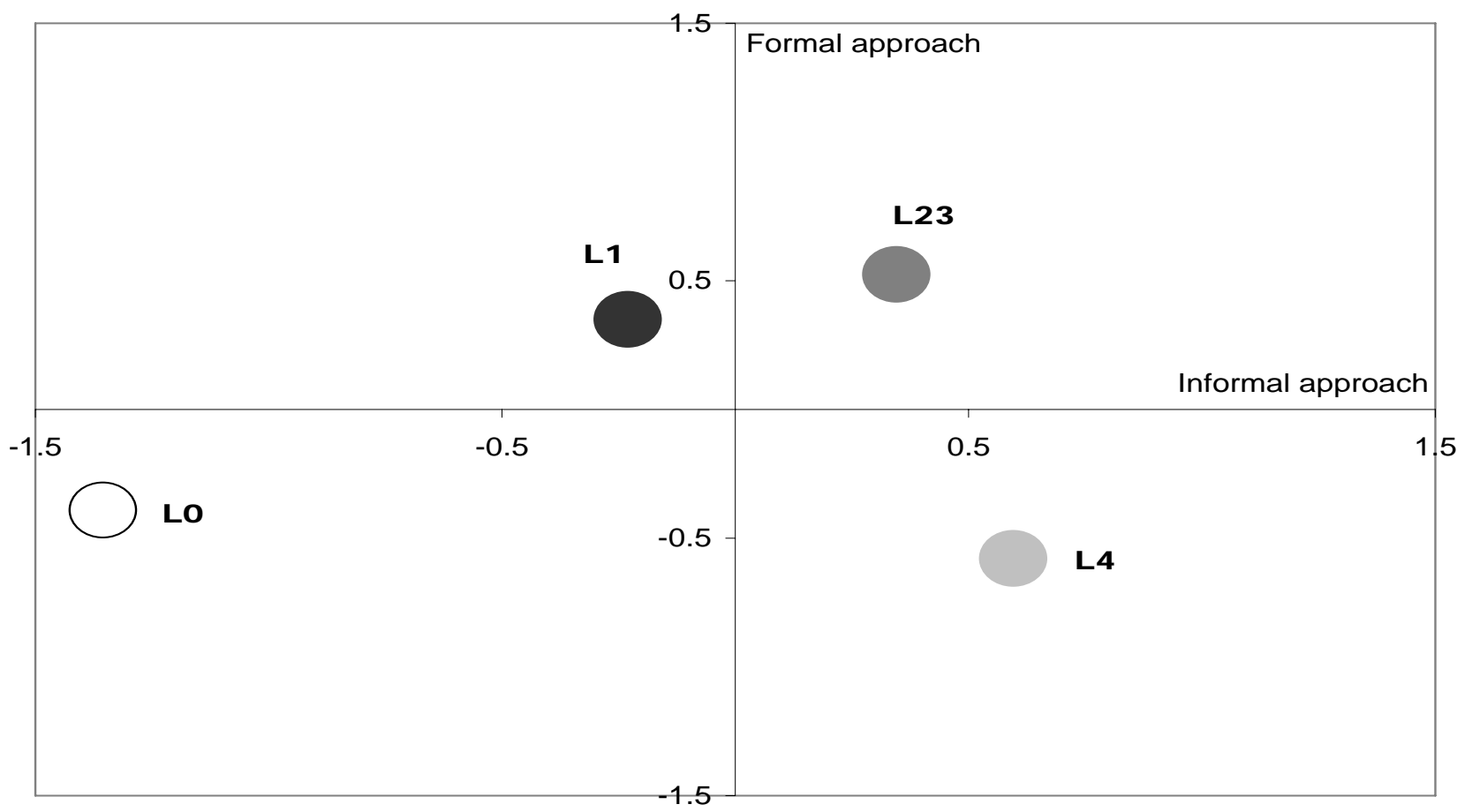

The connection between the different types of leaders and the level of trust in an organization

In the article (Kovač/Jesenko 2006), we found that an increased use of formal elements of leadership decreases trust within organizations, whereas the use of informal elements of leadership increases it. If we take the above analyses into consideration, which establishes that the types of leaders differ with regard to 
their use of formal and informal approaches to leadership, we can conclude that the level of trust received by these leaders from their subordinates also differs.

The research questionnaire measured the level of trust at various levels (within an organization, the top leaders, the superiors and subordinates and the organizational units). The trust between respondent and superior, who was evaluated from the democratic leadership point of view, thus best describes the level of trust between the superiors and the subordinates; the respondents evaluated trust on a five-level scale (1 - very low level of trust, .... 5 - very high level of trust). In order to find out whether individual types of leaders differ with regard to the established level of trust of the subordinates, we performed oneway analysis of variance (ANOVA), so that we could reject the null hypothesis that claims that the four types of leaders are equal with regard to the average value of trust (Table 10).

Table 10. ANOVA for Equality of Means between the different types of leader for trust between superiors and their subordinates

\begin{tabular}{|l|c|c|c|c|c|}
\hline & & & & \\
& Sum of squares & df & Mean square & F & Sig. \\
\hline Between groups & 27.655 & 3 & 9.218 & 9.905 & 0.000 \\
\hline Within groups & 89.345 & 96 & 0.931 & & \\
\hline Total & 117.000 & 99 & & & \\
\hline
\end{tabular}

The paired comparisons between the average group values (table 11) show that, with regard to trust, leaders of type L0 and L1, and of type L23 and L4 do not differ statistically; however, we noted statistically significant differences between the leaders of types L0, L23 and L4, as well as between leaders of types L1, L23 and L4.

Table 11. Multiple comparisons

\begin{tabular}{|c|c|c|c|c|}
\hline (I) Type of leader & (J) Type of leader & $\begin{array}{c}\text { Mean } \\
\text { Difference } \\
\left(\bar{x}_{I}-\bar{x}_{J}\right)\end{array}$ & $\begin{array}{c}\text { Std. } \\
\text { Error }\end{array}$ & Sig. \\
\hline L0 & L1 & -0.335 & 0.314 & 0.289 \\
\hline & L23 & $-1.154\left(^{*}\right)$ & 0.322 & 0.001 \\
\hline L1 & L4 & $-1.339\left(^{*}\right)$ & 0.309 & 0.000 \\
\hline & L0 & 0.335 & 0.314 & 0.289 \\
\hline & L23 & $-0.819\left(^{*}\right)$ & 0.263 & 0.002 \\
\hline L23 & L4 & $-1.004\left(^{*}\right)$ & 0.247 & 0.000 \\
\hline & L0 & $1.154\left(^{*}\right)$ & 0.322 & 0.001 \\
\hline L4 & L1 & $0.819\left(^{*}\right)$ & 0.263 & 0.002 \\
\hline & L4 & -0.185 & 0.258 & 0.474 \\
\hline & L0 & $1.339\left(^{*}\right)$ & 0.309 & 0.000 \\
\hline & L1 & $1.004\left(^{*}\right)$ & 0.247 & 0.000 \\
\hline & L23 & 0.185 & 0.258 & 0.474 \\
\hline
\end{tabular}

*The mean difference is significant at the .05 level. 
Figure 6 shows the average values of trust among the four types of leaders, from which we can deduce that the more democratic approach to leadership brings about an increased feeling of trust among the superiors and subordinates; the differences are statistically significant. Therefore, we found that democratic leaders enjoy a higher level of trust among their subordinates, which confirms our second working hypothesis.

Figure 6. The average level of trust among the superiors and the subordinates, as observed in the four types of leaders

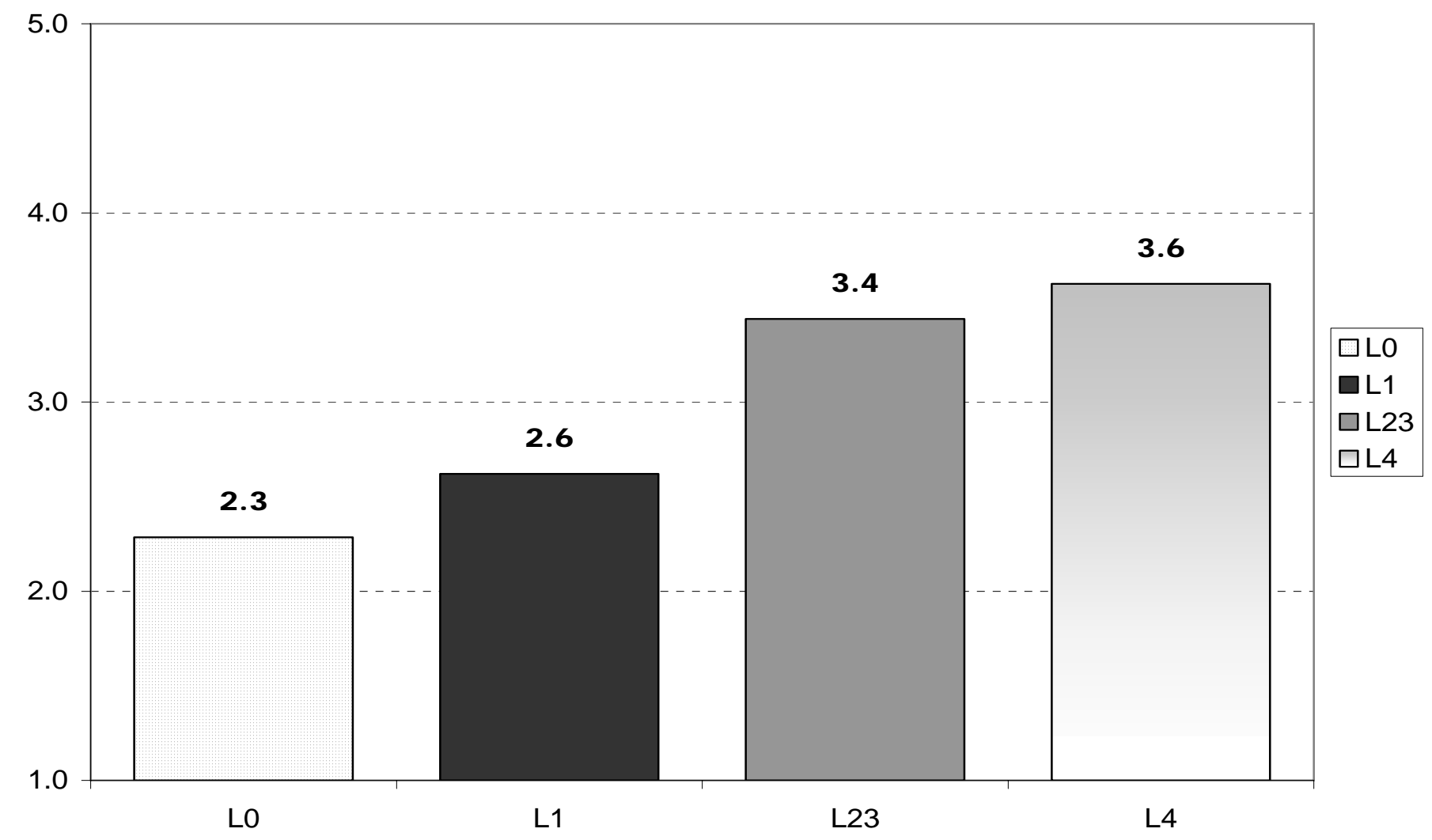

\section{Conclusions and future research}

With our research, we wanted to discover whether statistically significant connections exist between the level of democracy in leadership styles and the level of the inclusion of formal and informal elements into the processes of task delegation, communication and control, as well as between the level of trust among the subordinates and the superiors.

The definitions of the democratic leadership approaches were based on the four previously defined leadership styles; however, the elements of the individual types of leaders that determine a democratic or non-democratic approach were measured separately. By using cluster analysis, we were able to define four new groups of leaders; three groups (marked as L1, L23 and L4) coincide provisionally with a theoretically defined group of leaders and thus reflect their 
level of democracy. The fourth group is of a new type of leader, whom his subordinates cannot define as either an authoritative or a democratic leader; his behaviour is perceived as feeble, indecisive and uncooperative (we marked him as type L0).

With discriminant analysis, we discovered that the four groups of leaders studied differ in their use of formal and informal elements in the processes of task delegation, communication and control. Informal elements of communication and control showed greater distinguishing power. Furthermore, we found that an increased level of democracy in leadership brings about an increased use of informal leadership elements and a decreased use of formal leadership elements (and vice versa). It is interesting that type L0 leaders - when compared with other types of leaders - use both formal and informal elements studied to a lesser degree in the examined leadership processes; this inidicates a lower level of cooperation and connection with the employees.

A comparison of trust between the four groups of leaders studied showed that by increasing the level of democracy in leadership, an increased level of trust occurs between the superiors and the subordinates. Type L0 leaders - who cannot be defined as non-democratic due to their behaviour - enjoy the lowest level of trust and do not differ in a statistically significant manner from the least democratic leaders of type L1. This shows how important personal strength and determination are for top leaders when establishing the trust of their subordinates.

The results obtained in the analyses indicate the connection between the level of democracy in leadership and the level of formalisation in delegating tasks, communication and controlling the tasks of one's subordinates, as well as the democracy in leadership and the level of trust. In this respect, it should also be taken into account that the results do not show cause and effect connections, only connections between the observed phenomena. Therefore, further research should pay greater attention to the reliability and validity of the measured constructs. In other words, it would be necessary to define the formalisation or non-formalisation of the studied constructs in greater detail and to determine their validity through ongoing research. Therefore, we can only view the results of the research presented as a preliminary study that shows theoretically predicted connections between the observed phenomena and, as such, presents the basis for more in-depth research into the connection between democracy in leadership and the level of formalisation in the leadership processes of leaders, as well as the connection between democracy in leadership and trust within an organisation. In our further research, we plan to focus on the cause and effect connections between the observed constructs; however, this will require a more detailed definition of the constructs and a larger sample of units studied.

In the area of developing trust theories, we can establish the confirmation of individual theoretical concepts on the positive impact of the level of trust on the 
leadership process within an organization. At the same time, the established results represent a motivation for further research of the correlation between the level of trust within the entire process and leadership style, and organizational dimensions.

\section{References}

Andersen, A.J. (2005): Trust in managers: a study of why Swedish subordinates trust their managers, in: Business Ethics - A European Review, 14, 4, 392-404.

Barney, J.B./Hansen, M.H. (1994):Trustworthiness as a source of competitive advantage, in: Strategic Management Journal 15, 1994, 175-190.

Bass, B.M. (1990): Bass and Stogdill's handbook of leadership. New York: Free Press.

Bibb, S./Kourdi, J. (2007): A Question of Trust: The crucial nature of trust in business, work and life-and how to build it. London: Cyan Communications.

Bijlsam-Frankie, K./Klein Wolthuis, R. (2005): Trust under pressure. Cheltenham: Edward Elgar Publishing.

Bijlsma-Frankema, K./de Jong, B./van de Bunt, G. (2008): Heed, a missing link between trust, monitoring and performance in knowledge intensive teams, in: The International Journal of Human Resource Management, 19, 1, 19-40.

Bleicher, K. (1991): Organisation. Wiesbaden: Gabler.

Bleicher, K. (2009): Die Vision von der intelligenten Unternehmung als Organistaionsform der Wissensgesellschaft, in: Zeitschrift Führung +Organisation, 78, 2, 72-79.

Certo, C.S. (1999):Modern Management. New Jersey: Prentice Hall.

Coenders, G./Casas, F./Figuer, C./Gonzàlez, M. (2003): Relationships between parents' and children's values and children's overall life satisfaction - A comparison across countries. Paper presented at the 5th Conference of the International Society for Quality-of-Life Studies, Johann Wolfgang-University, Frankfurt am Main.

Das, T.K./Teng, B.S. (1998): Between trust and control, Developing confidence in partner cooperation in alliances, in: Academy of Management Review, 23, 3, 491-512.

Dessler, G. (2001): Management. New Jersey: Prentice Hall.

Dirks, K.T./Ferrin, D.L. (2002): Trust and leadership, Meta-analytic findings and implications for organizational research, in: Journal of Applied Psychology, 87,4, 611-628.

Dirks, K.T./Skarlicki, D.P. (2004): Trust in leaders: Existing research and emerging issues, in: Kramer, R.M./Cook, K.S. (ed.): Trust and distrust in organizations. New York: Russell Sage.

Fleishman, E.A./Harris, E.F. (1962): Patterns of leadership behavior related to employee grievances and turnover, in: Personnel Psychology,15, 1, 43-56.

Hill, C.W.L. (1990): Cooperation, opportunism and the invisible hand: Implications for transaction cost theory, in: Academy of Management Review, 15, 3, 500-513.

Hogan, R./Curphy, G.J./Hogan, J. (1994): What we know about leadership. Effectiveness and personality, in: American Psychologist, 49, 6, 439-504. 
Ghilic-Micu, B./Stoica, M. (2003): Trust and fear in the virtual organization, in: Economy Informatics, 3, 24, 16-20.

Khalil, E.L. (2003): Trust. Cheltenham: Edward Elgar Publishing.

Kirkpatrick, S.A./Locke, E.A (1996): Direct and indirect effects of three core charismatic leadership components on performance and attitudes, in: Journal of Applied Psychology, 81, 2, 36-51.

Kovač, J./Jesenko, M. (2004): The level of trust in companies in Slovenia. In: Jaškova, M. (ed.) ECON '04: Research works proceedings, 11, 2004. Ostrava: Technical University of Ostrava, Faculty of Economics, 155-160.

Kovač, J./Jesenko, M. (2006): The level of trust in companies in Slovenia, in: The organizing society: 22nd EGOS Colloquium, Bergen, 07, 06, 6-8,. Bergen: EGOS.

Korsgaard, M.A./Roberson, L. (1995.): Procedural justice in performance evalution, in: Journal of Management, 21, 3, 657-699.

Kramer, R.M./Cook, K.S. (ed.). (2004): Trust and distrust in organizations. New York: Russell Sage.

Lang, R. (ed.) (1996): Wandel von Unternehmenskulturen in Ostdeutschland und Osteuropa. Mering: Rainer Hampp Verlag.

Nooteboom, B. (2002):Trust. Cheltenham: Edward Elgar Publishing.

Nooteboom, B./Six, F. (2003): The Trust Process in Organisations. Cheltenham: Edward Elgar Publishing.

Neubauer, W./Rosemann, B. (2006): Führung, Macht und Vertrauen in Organisation. Stuttgart: Verlag W. Kohlhammer.

Ortmann, G./Sydow, J./Turk, K. (1997): Theorien der Organisation. Opladen: Westdeutscher Verlag.

Podsakoff, P.M. (ed.) (1990): Transformational leader behaviors and their effects on followers trust in leader, satisfaction, and organizational citizenship behaviors, in: Leadership Quarterly, 2, 1, 701-716.

Robbins, S.P./DeCenzo, D.A. (2001): Management. New Jersey: Prentice Hall.

Rosenstiel, L.V. (2000): Grundlagen der Organisationspsychologie. Stuttgart: SchäfferPoeschel Verlag.

Schriesheim, C.A./Castro, S./Cogliser, C.C. (1999): Leader-member exchange (LMX) research: A comprehensive review of theory, measurement, and data-analytic procedures, in: Leadership Quarterly, 10, 1, 63-113.

Schweer, M./Thies, B. (2003): Vertrauen als Organisationsprinzip. Bern: Hans Huber Verlag.

Sharma, S. (1996): Applied Multivariate Techniques. New Jersey: John Wiley and Sons.

Staehle, W. (1999): Management. Munich: Verlag Franz Vahlen.

Willemyns, M./Gallois, C./Callas, V.J. (2003): Trust me, I’m your boss: Trust and power in supervisor-supervisee communication, in: The International Journal of Human Resource Management, 14, 1, 117-127.

Williamson, O.E. (1975): Markets and Hierarchies: Analysis and Antitrust Implication. New York: Free Press. 
Williamson, O.E. (1985): The economic institutions of capitalism: Firms, markets, relational contracting. New York: The Free Press.

Williamson, O.E. (1993): Calculativeness, trust and economic organization, in: Journal of Law and Economics, 36, 04, 453-486.

Whitener, E.M. (ed.) (1998): Managers as initiators of trust: an exchange relationship framework for understanding managerial trustworthy behavior, in: Academy of Management Review, 23, 3, 513-530.

Zand, D.E. (1977): Vertrauen und Problemlösungsverhalten von Managern. In: Lück, H.E. (ed,): Mitleid, Vertrauen, Verantwortung, in: Ergebnisse der Erforschung prosozialen Verhaltens, Stuttgart.

Zeffane, R./Connell, J. (2003): Trust and HRM in the new millennium, in: International Journal of Human Resource Management, 14, 1, 1-11. 